\title{
Chemical Control of Potato Tuber Moth (PTM), Phthorimaea operculella (Zeller) on Two Potato Varieties under Field Conditions. Gamal El-din, A. H. ${ }^{1}$; A. E. Abdelmonem ${ }^{1}$; S. A. Hammad ${ }^{2}$ and M. F. El-Tawil ${ }^{1}$. Plant Protection Department, ${ }^{1}$ Division of Pesticides, ${ }^{2}$ Economic Entomology, Faculty of Agriculture, Al-Azhar University, Cairo, Egypt
}

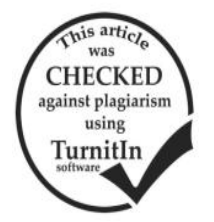

\begin{abstract}
The present work aimed to evaluate the efficiency of three insecticides [indoxacarb (Avaunt 15\% EC), lufenuron (Match $5 \%$ EC) and methoxyfenozide (Runner 24\% SC)] at their recommended rates at two different spray times of 10 or 15 days after the first spray against potato tuber moth (PTM), Phthorimaea operculella (Zeller) larvae on two potato varieties (Spunta and Mondial) during two successive summer seasons 2014 and 2015 at Appig village, Kafer El-zyaat center, Gharbia Governorate, Egypt. A randomized complete block design was applied for treatments including untreated check. The results showed that for 10 days experiments at season 2014, all treatments achieved reduction of PTM population in the foliage infestation when the highest values were recorded with Avaunt (46.29\% \& 41.97\%) followed by Runner (34.84 \% \& 28.10 \%) and Match (33.04\% \& $26.53 \%$ ), for Spunta and Mondial varieties, respectively. The same trend was also recorded during the season of 2015. However, for 15 days experiments during season 2014, all treatments showed reduction of PTM population in the foliage infestation when the highest values were recorded with Avaunt (54.46\% \& 61.41\%) followed by Runner (47.01 \% \& $47.47 \%$ ) and Match (41.18\% $\& 44.51 \%$ ), for Spunta and Mondial varieties, respectively. The same trend was also recorded at season 2015. Generally, all treatments achieved reduction of PTM population in the foliage infestation and resulted in increasing the potato yield of two varieties compared with untreated check. Fifteen days experiments were more appropriate than ten days where, Spunta variety was more susceptible to foliage infestation than Mondial variety.
\end{abstract}

Keywords: potato tuber moth, potato varieties, indoxacarb, methoxyfenozide, lufenuron, insecticides.

\section{INTRODUCTION}

Potato, Solanum tuberosum L. is a major food crop in many countries of the world. It occupies the forth place among the most important food crops all over the world, following wheat, rice, and maize (Shady et al., 2007).

In Egypt, potato is considered as a major energy - rich crop and it is consumed for its high food contents and it is also required for exportation, representing one of the most important sources of national income (Shoeb, Mona and mostafa, 2004). The whole cultivated area was 381379 fed which produced 4265178 tons, by average of $11.18 \mathrm{ton} / \mathrm{fed}$. in 2013 of all seasons (Sharshar et al., 2015). Egypt ranks among the world's top potato exporters (Mohamed et al., 2013).

Potato is used to make medicine for therapy of stomach disorders, control appetite for weight loss, infections, boils, burns, cramps, insomnia, cough and diabetes. Also potatoes contain provitamin A, vitamin $\mathrm{K}$, sulfur and vitamin C. (Umadevi et al., 2013).

Potatoes are liable to infestation by many insect pests, which reduce yield quantity and quality. Potato tuber moth, Phthorimaea operculella is considered to be one of the most serious insect pests infesting family Solanaceae (Sarhan, 2004 and Mandour et al., 2012).

In Egypt, potato tuber moth has caused up to $100 \%$ losses to potato plants in fields as well as in storage (Ahmed et al., 2013).

The most common control method for $P$. opercullela is the used of various insecticides (Dillard et al., 1993). These insecticides such as insect growth regulators (IGRs) and oxadiazine are widely used to control this pest. Insect growth regulators can be divided according to their mode of action into two major groups; chitin synthesis inhibitors (i.e. lufenuron) and substances that interfere with the action of insect hormones (methoxyfenozide) (Tunaz and Uygun, 2004). Indoxacarb is especially active on foliar-feeding lepidopteran larvae (Sansone and Minzenmayer, 2000); it blocks the sodium channel and is reported to be a slow-acting insecticide with relatively long residual activity (Andaloro, et al. 2000).

This work aimed to evaluate the effect of three insecticides (i.e. indoxacarb, lufenuron and methoxyfenozide) at two different spraying times, (two different experiments and two applications at 10 or 15 days) against $P$. operculella larvae on two potato varieties (Spunta and Mondial) during two successive summer seasons of 2014 and 2015.

\section{MATERIALS AND METHODS}

Field experiments were carried out in Appig village, Kafer El-zyaat center, Gharbia Governorate during two successive summer seasons, 2014 and 2015. An area of $1680 \mathrm{~m}^{2}$ was divided into 8 plots; each plot was subdivided into 5 replicates (each replicate $42 \mathrm{~m}^{2}$ ) for each treatment. The plot of control subjected to natural infestation. A randomized complete block design was applied for each plot including the control. Spunta and Mondial varieties were selected and planted in $1^{\text {st }}$ and $3^{\text {rd }}$ Jan. at 2014 and 2015 , respectively. These varieties were obtained from the International Potato Center, Kafer Al-Zayate, Gharbia Governorate, Egypt. The usual seeding practices were applied by sowing in $25 \mathrm{~cm}$ apart in rows ( $80 \mathrm{~cm}$ wide) with the soil ridged up to bury the tuber seeds at a depth $20 \mathrm{~cm}$ below soil surface. Irrigation intervals and fertilization were conducted as usual. Two chemical applications were applied for all treatments; the first spray was applied 75 days after sowing whereas the second spray was applied 10 days (first experiment) or 15 days (second experiment) after the first spray during 2014 and 2015 seasons.

\section{Insecticides used:}

1-Indoxacarb insecticide:

Trade name : Avaunt 15\% EC 
Rate of application : $50 \mathrm{ml} / 200$ liter/fed.

2-Methoxyfenozide insecticide:

Trade name : : Runner 24\% SC

Rate of application : $150 \mathrm{ml} / 200$ liter/fed.

3-Lufenuron insecticide:

Trade name : Match 5\% EC

Rate of application : $160 \mathrm{ml} / 200$ liter/fed.

Foliage samples:

Foliage samples of 50 leaves were taken randomly from each plot as follows:

1-Before the first spray immediately samples were collected 75 days after sowing.

2-After the first spray samples were collected 10 days (for the first experiment) and 15 days (for the second experiment).

3-After the second spray samples were collected 10 days (for the first experiment) and 15 days (for the second experiment).

The formula of Henderson \& Tilton (1955) was used to calculate the percentage of reduction in the pest population.

Reduction \% $=(1-\mathrm{A} / \mathrm{B} \times \mathrm{C} / \mathrm{D}) \times 100$

$A=$ Number of live larvae in the treatment after application.

$\mathrm{B}=$ Number of live larvae in the treatment before application.

$\mathrm{C}=$ Number of live larvae in the control before application.

$\mathrm{D}=$ Number of live larvae in the control after application.

Yield increase \% was calculated using the following formula:
$\%$ increase in yield $=\underset{T}{T} \times 100$

$\mathrm{T}=$ weight of yield in the treatment plot.

$\mathrm{C}=$ weight of yield in the untreated plot.

Statistical methods:

Data were subjected to ANOVA by using Costat program (1988) and significant differences among the treatments was portioned by LSD test at $P=0.05$ level.

\section{RESULTS AND DISCUSSION}

Effect of insecticides used on the potato tuber moth (PTM) larval mortality in potato leaves:

Field evaluations of three insecticides [i.e. indoxacarb (Avaunt 15\% EC), lufenuron (Match 5\% EC) and methoxyfenozide (Runner $24 \%$ SC)] against potato tuber moth, Phthorimaea operculella (Zeller) larvae in two potato varieties for two sprays were studied. The first spray was applied 75 days after sowing whereas the second spray was applied 10 days (first experiment) or 15 days (second experiment) after the first spray during 2014 and 2015 seasons.

Experiments of 10 days:

Results of table (1) revealed that, at season 2014, all treatments achieved reduction of PTM population in foliage infestation, while the highest values were recorded with Avaunt $(46.29 \%$ \& $41.97 \%)$ followed by Runner (34.84 \% \& $28.10 \%)$ and Match $(33.04 \%$ \& $26.53 \%$ ), for Spunta and Mondial varieties, respectively. The same trend was also recorded at season 2015, which ranged from $49.54 \%$ and $54.31 \%$ for Avaunt $40.95 \%$ and $40.25 \%$ in case of Match for Spunta and Mondial varieties, respectively.

Table 1. Effect of the second spray after 10 days of insecticide applications on the population reduction of potato tuber moth larvae in the leaves of two potato varieties (Spunta \& Mondial) under field conditions during 2014 and 2015 seasons.

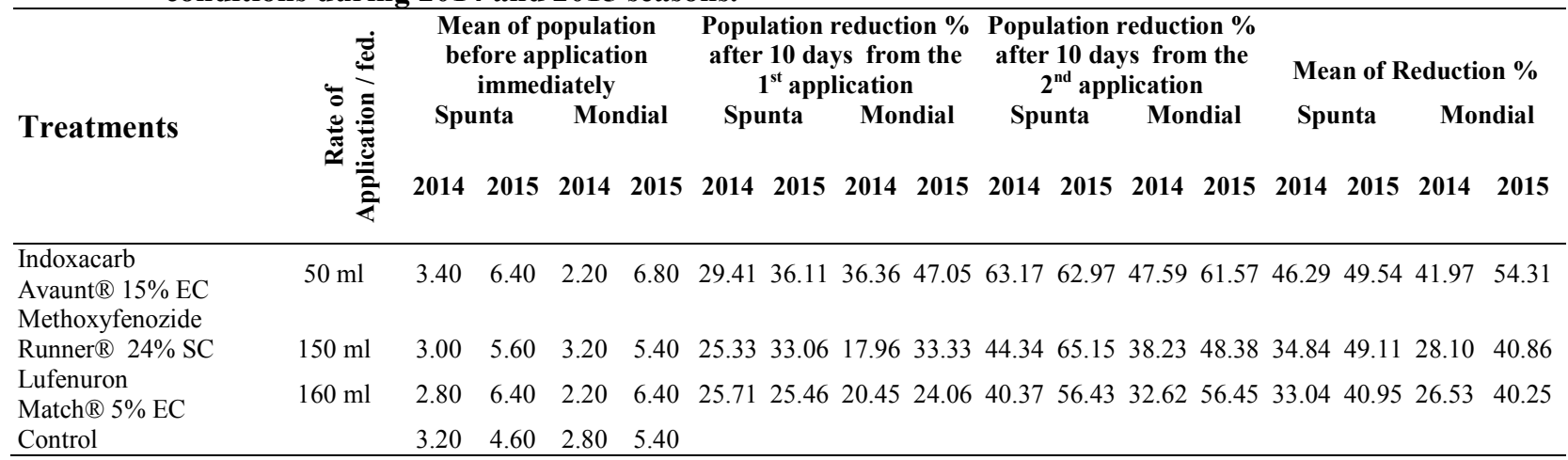

The statistical analysis of table (2) showed that, in season 2014, all treatments had a significant effect in reducing larval infestation compared with untreated check, except Runner with Mondial variety, while there was no significance between the tested compounds except between Avaunt and Runner with Mondial variety and there was less significant infestation found between two potato varieties. On the other side, there was significant variation between the efficacy of $1^{\text {st }}$ and $2^{\text {nd }}$ sprayes in two cases; first was Avaunt treatment on
Spunta variety whereas the second was Runner treatment on Mondial variety.

The statistical analysis of the results during season 2015 showed that, all treatments had a significant reduction in larval infestation compared with untreated check, whereas no significant reductions were observed between the tested compounds except Runner and Match on Spunta variety. For sprays, the results indicated that, there was significant reduction between all treatments. However, there were no significant reductions between the varieties. 
Gamal El-din, A. H. et al.

Table 2. Effect of the second spray after 10 days of insecticide applications on potato tuber moth larval infestation in the leaves of two potato varieties (Spunta \& Mondial) under field conditions during 2014 and 2015 seasons.

\begin{tabular}{|c|c|c|c|c|c|c|c|}
\hline \multirow[t]{2}{*}{ Treatment } & \multirow{2}{*}{$\begin{array}{l}\text { Application } \\
\text { (sprays) }\end{array}$} & \multicolumn{4}{|c|}{ Number of larval infestation of 10 days } & \multicolumn{2}{|c|}{ Mean of 10 days } \\
\hline & & 2014 & 2015 & 2014 & 2015 & 2014 & 2015 \\
\hline \multirow{3}{*}{ 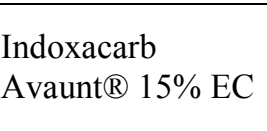 } & $1^{\text {st }}$ & $* 3.00$ & 4.80 & 1.60 & 4.00 & 2.30 & 4.40 \\
\hline & $2^{\text {nd }}$ & 1.80 & 3.40 & 1.44 & 3.00 & 1.60 & 3.20 \\
\hline & Mean & 2.40 & 4.10 & 1.50 & 3.50 & 1.95 & 3.80 \\
\hline \multirow{3}{*}{$\begin{array}{l}\text { Methoxyfenozide } \\
\text { Runner® } 24 \% \text { SC }\end{array}$} & $1^{\text {st }}$ & 2.80 & 4.40 & 3.00 & 4.00 & 2.90 & 4.20 \\
\hline & $2^{\text {nd }}$ & 2.40 & 2.80 & 2.40 & 3.20 & 2.40 & 3.00 \\
\hline & Mean & 2.60 & 3.60 & 2.70 & 3.60 & 2.65 & 3.60 \\
\hline \multirow{4}{*}{$\begin{array}{l}\text { Lufenuron } \\
\text { Match® }{ }^{2} \% \text { EC }\end{array}$} & $1^{\text {st }}$ & 2.60 & 5.60 & 2.00 & 5.40 & 2.30 & 5.50 \\
\hline & $2^{\text {nd }}$ & 2.40 & 4.00 & 1.80 & 3.20 & 2.10 & 3.60 \\
\hline & Mean & 2.50 & 4.80 & 1.90 & 4.30 & 2.20 & 4.55 \\
\hline & $1^{\text {st }}$ & 4.00 & 5.40 & 3.20 & 6.00 & 3.60 & 5.70 \\
\hline \multirow{2}{*}{ Control } & $2^{\text {nd }}$ & 4.60 & 6.60 & 3.40 & 6.20 & 4.00 & 6.40 \\
\hline & Mean & 4.30 & 6.00 & 3.30 & 6.10 & 3.80 & 6.05 \\
\hline Mean & & 2.95 & 4.63 & 2.35 & 4.37 & 2.65 & 4.50 \\
\hline
\end{tabular}

*Mean number of live larvae of five replicates (50 leaves each)

$\begin{array}{llll}\text { L.S.D. values at 5\% } & 2014 & 2015 \\ \text { Treatment } & \text { (T.) } & \mathbf{0 . 8 2} & \mathbf{0 . 9 6} \\ \text { Variety } & \text { (V.) } & \mathbf{0 . 5 8} & \mathbf{0 . 6 8} \\ \text { Application } & \text { (A.) } & \mathbf{0 . 5 8} & \mathbf{0 . 6 8} \\ \mathbf{T} * \mathrm{~V} & & \mathbf{1 . 1 6} & \mathbf{1 . 3 6} \\ \mathbf{A} * \mathbf{T} & & \mathbf{1 . 1 6} & 1.36 \\ \mathbf{A} * \mathrm{~V} & & \mathbf{0 . 8 2} & \mathbf{0 . 9 6} \\ \mathbf{A} * \mathbf{T} * \mathrm{~V} & & \mathbf{1 . 6 5} & \mathbf{1 . 9 2}\end{array}$

\section{Experiments of 15 days:}

Results of table (3) revealed that, during season 2014, all treatments produced reduction of PTM population in foliage infestation when the highest values were recorded with Avaunt (54.46\% \& 61.41\%) followed by Runner (47.01\% \& $47.47 \%$ ) and Match (41.18\% \& 44.51\%), for Spunta and Mondial varieties, respectively. The same trend was also recorded at season 2015.

The data in table (4) showed that, during season 2014, all treatments had a significant effect in reduction of larval infestation compared with untreated check, but there were no significant differences between the tested compounds, except in the effect of Avaunt and Match treatments on Mondial variety. There were significant differences between the sprays for all treatments.

However, the results indicated that during season 2015, the treatments had a significant reduction in larval infestation compared with untreated check, but there was no significant reduction between the tested compounds. However, there was significant reduction between the sprays for all treatments. But there was no significant difference in the infestations of two potato varieties.

Table 3. Effect of the second spray after 15 days of insecticide applications on the population reduction of potato tuber moth larvae in the leaves of two potato varieties (Spunta \& Mondial) under field conditions during 2014 and 2015 seasons.

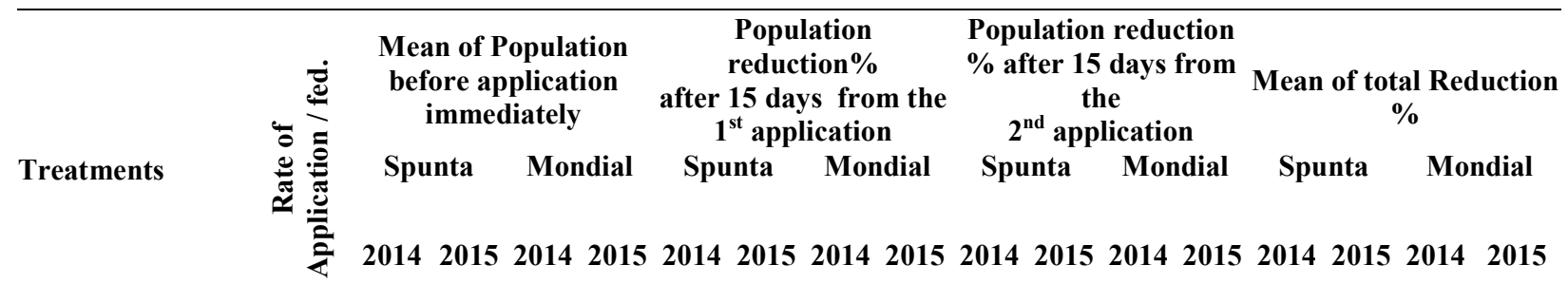

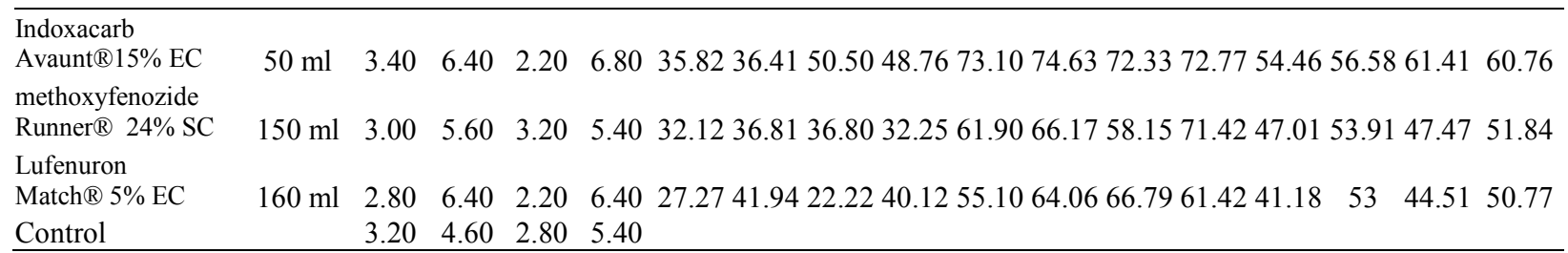


Gamal El-din, A. H.

Table 4. Effect of the second spray after 15 days of insecticide applications on potato tuber moth larval infestation in the leaves of two potato varieties (Spunta \& Mondial) under field conditions during 2014 and 2015 seasons.

\begin{tabular}{|c|c|c|c|c|c|c|c|}
\hline \multirow{3}{*}{ Treatment } & \multicolumn{5}{|c|}{ Number of larval infestation of 15 days } & \multirow{2}{*}{\multicolumn{2}{|c|}{ Mean of 15 days }} \\
\hline & \multirow{2}{*}{$\begin{array}{c}\text { Application } \\
\text { (sprays) }\end{array}$} & \multicolumn{2}{|c|}{ Spunta } & \multicolumn{2}{|c|}{ Mondial } & & \\
\hline & & 2014 & 2015 & 2014 & 2015 & 2014 & 2015 \\
\hline \multirow{3}{*}{$\begin{array}{l}\text { Indoxacarb } \\
\text { Avaunt } \AA 15 \% \text { EC }\end{array}$} & $1^{\mathrm{st}}$ & $* 3.00$ & 4.60 & 4.10 & 4.00 & 3.55 & 4.30 \\
\hline & $2^{\text {nd }}$ & 1.60 & 2.20 & 1.00 & 2.40 & 1.30 & 2.30 \\
\hline & Mean & 2.30 & 3.40 & 2.55 & 3.20 & 2.43 & 3.30 \\
\hline \multirow{3}{*}{$\begin{array}{l}\text { Methoxyfenozide } \\
\text { Runner® } 24 \% \text { SC }\end{array}$} & $1^{\text {st }}$ & 2.80 & 4.00 & 2.60 & 4.20 & 2.70 & 4.10 \\
\hline & $2^{\text {nd }}$ & 2.00 & 2.40 & 2.00 & 2.80 & 2.00 & 2.60 \\
\hline & Mean & 2.40 & 3.20 & 2.30 & 3.50 & 2.35 & 3.35 \\
\hline \multirow{4}{*}{$\begin{array}{l}\text { Lufenuron } \\
\text { Match } \AA 5 \% \text { EC }\end{array}$} & $1^{\text {st }}$ & 2.80 & 4.20 & 2.20 & 4.40 & 2.50 & 4.30 \\
\hline & $2^{\text {nd }}$ & 2.20 & 3.40 & 1.20 & 3.20 & 1.70 & 3.30 \\
\hline & Mean & 2.50 & 3.80 & 1.70 & 3.80 & 2.10 & 3.80 \\
\hline & $1^{\text {st }}$ & 4.40 & 5.20 & 3.60 & 6.20 & 4.00 & 5.70 \\
\hline \multirow{2}{*}{ Control } & $2^{\text {nd }}$ & 5.60 & 6.80 & 4.60 & 7.00 & 5.10 & 6.90 \\
\hline & Mean & 5.00 & 6.00 & 4.10 & 6.60 & 4.55 & 6.30 \\
\hline Mean & & 3.05 & 4.10 & 2.66 & 4.28 & 2.86 & 4.19 \\
\hline
\end{tabular}

*Mean number of live larvae of five replicates (50 leaves each)

$\begin{array}{llll}\text { L.S.D. values at 5\% } & 2014 & 2015 \\ \text { Treatment } & \text { (T.) } & 0.83 & 1.06 \\ \text { Variety } & \text { (V.) } & 0.59 & 0.74 \\ \text { Application } & \text { (A.) } & 0.59 & 0.74 \\ \text { T } * \text { V } & & 1.18 & 1.49 \\ \text { A } * \text { T } & & 1.18 & 1.49 \\ \text { A } * \text { V } & & 0.83 & 1.06 \\ \text { A } * \text { T } * V & & 1.67 & 2.12\end{array}$

The relation between chemical control and potato yield:

Experiments of 10 days:

Data of table (5) indicated that, all tested compounds resulted in increasing the potato yield of the two varieties compared with untreated check. There was significantly different for all treatments at season 2015 but there were no significant difference between the varieties in both seasons.

Consequently, the overall findings showed that potato yield was the highest when treated by Avaunt while the lowest gained when potato fields were applied by Match. Implementing Runner resulted in an intermediate potato yield (table 5).

Table 5. The relation between chemical control and potato yield of the second spray after 10 days of two potato varieties (Spunta and Mondial) during 2014 and 2015 seasons.

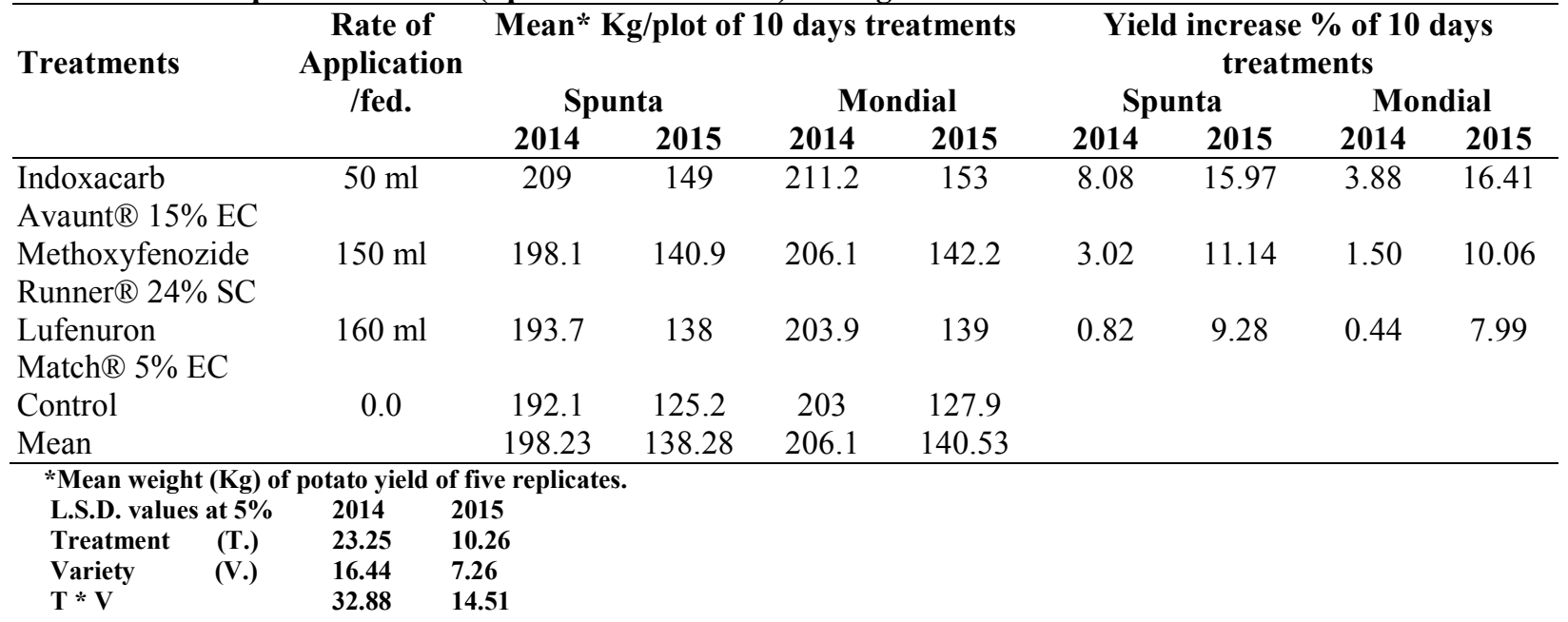

\section{Experiments of 15 days:}

Data of table (6) demonstrated that, all tested compounds resulted in increasing the potato yield of the two varieties compared with untreated check. For season 2014, there were significantly of treatments compared with untreated check in Avaunt with the two varieties and Runner with Mondial variety. For season 2015, there were significantly of all treatments compared with untreated check except only in the case of Match with Spunta variety. 
Generally, the present investigation demonstrated that, all treatments had a significant reduction of larval infestation resulted in increasing the potato yield compared with untreated check, thence indoxacarb was the hightest effect followed by methoxyfenozide and lufenuron. These results are in agreement with VanevaGancheva and Dimitrov (2013) cited that, the best control over potato tuber moth can be exercised by chlorantraniliprole and indoxacarb and the effectiveness under field conditions has been manifested by ensuring a longer period of protection. Dobie (2010) showed the most continuous effect of indoxacarb against young caterpillars of the potato tuber moth compared with other tested compounds. The weak initial effect of indoxacarb is because the latter had to be swallowed by the caterpillars and metabolized to a bioactive metabolite. It is possible that indoxacarb was less efficacious because this compound has a slower mode of action as it has to be ingested and metabolized to DCMP, the bioactive metabolite.

Table 6. The relation between chemical control and potato yield of the second spray after 15 days of two potato varieties (Spunta and Mondial) during 2014 and 2015 seasons.

\begin{tabular}{|c|c|c|c|c|c|c|c|c|c|}
\hline \multirow{3}{*}{ Treatments } & \multirow{3}{*}{$\begin{array}{c}\text { Rate of } \\
\text { Application } \\
\text { /fed. }\end{array}$} & \multicolumn{4}{|c|}{$\begin{array}{c}\text { Mean* Kg/plot of } 15 \text { days } \\
\text { treatments }\end{array}$} & \multicolumn{4}{|c|}{$\begin{array}{c}\text { Yield increase \% of } 15 \text { days } \\
\text { treatments }\end{array}$} \\
\hline & & \multicolumn{2}{|c|}{ Spunta } & \multicolumn{2}{|c|}{ Mondial } & \multicolumn{2}{|c|}{ Spunta } & \multicolumn{2}{|c|}{ Mondial } \\
\hline & & 2014 & 2015 & 2014 & 2015 & 2014 & 2015 & 2014 & 2015 \\
\hline $\begin{array}{l}\text { Indoxacarb } \\
\text { Avaunt }{ }^{\circledR} 15 \% \mathrm{EC}\end{array}$ & $50 \mathrm{ml}$ & 212.85 & 154 & 213.75 & 156 & 13.08 & 17.60 & 14.85 & 17.95 \\
\hline $\begin{array}{l}\text { Methoxyfenozide } \\
\text { Runner® } 24 \% \text { SC }\end{array}$ & $150 \mathrm{ml}$ & 204.72 & 148.1 & 208.68 & 149.2 & 9.63 & 14.31 & 12.78 & 14.20 \\
\hline $\begin{array}{l}\text { Lufenuron } \\
\text { Match® }{ }^{\circ} \% \mathrm{EC}\end{array}$ & $160 \mathrm{ml}$ & 195.95 & 140 & 203.94 & 143 & 5.59 & 9.36 & 10.75 & 10.48 \\
\hline Control & 0.0 & 185 & 126.90 & 182 & 128 & & & & \\
\hline Mean & & 199.63 & 142.25 & 202.09 & 144.1 & & & & \\
\hline \multicolumn{10}{|c|}{ *Mean weight (Kg) of potato yield of five replicates. } \\
\hline L.S.D. values at $5 \%$ & 2014 & & & & & & & & \\
\hline Treatment (T.) & 23.85 & & & & & & & & \\
\hline $\begin{array}{l}\text { Variety } \\
T * \mathbf{V}\end{array}$ & 16.87 & & & & & & & & \\
\hline
\end{tabular}

Mohamed (2002) reported that flufenoxuron insecticide gave significant effect on PTM infestation significant increase in potato yield compared to untreated check.

Shoeb, Mona and Mostafa (2004) studied the insecticidal effects of three IGRs [Match (lufenuron), Consult (hexaflumuron) and Cascade (flufenoxuron)] on potato tuber moth. They found that, using insect growth regulators may be recommended with planning I.P.M. programs against $P$. operculella.

In conclusion, the 15 days experiment was better than 10 days experiment where, Spunta variety was more susceptible of foliage infestation than Mondial variety. These findings are in agreement with VanevaGancheva and Dimitrov (2013) which reported that, the effectiveness under field conditions has been manifested by ensuring a longer period of protection. The best control over the potato tuber moth can be exercised by chlorantraniliprole and indoxacarb. Fourteen days after the first treatment the extent of damages of all tested compounds significantly decreased compared with the control.

Temerak (1979) reported that potato variety did not seem to play a significant role in increasing or decreasing the larval potency inside potato leaves after PTM attack it.

\section{REFERENCES}

Ahmed, A.A.I.; M.Y., Hashemb; S.M., Mohamed and S.H., Khalila, Shimaa (2013). Protection of potato crop against Phthorimaea operculella (Zeller) infestation using frass extract of two noctuid insect pests under laboratory and storage simulation conditions. Arc. of Phytopathology and Plant Protection. DOI: 10.1080/ 03235408. 2013. 795356.

Andaloro, J.T.; K.D., Wing; J.H., Green; E.B., Lang, and T.M., Steward (2000). Dispersion and cotton leaf interactions: impact on cotton insect pests and safety to beneficial arthropods. In Proceedings of 2000 Beltwide Cotton Conference, Dugger P. and Richter D. (Ed.). National Cotton Council, Memphis, TN. 939940.

Costat software. (1988). Microcomputer program analysis, CoHort software, Berkely, CA, USA.

Dillard, H.R.; T.J., Wicks and B., Philip (1993). A grower survey of diseases, invertebrate pests, and pesticide use on potatoes grown in South Australia. Aust. J. of Experimental Agric. 33:653-661.

Dobie, C. H. (2010). Pesticide Susceptibility of Potato Tuberworm in the Pacific Northwest (Doctoral dissertation, Washington State University).

Henderson, C.F. and E.W. Tilton (1955). Test with acaricides against the brown wheat mite (J. Econ. Ent., 48: 157 -161). 
Mandour, N.S.; A., Sarhan; H., Atwa and D.M., Soliman (2012). The integration between trichogramma evanescens Westwood (Hymenoptera : Trichogrammatidae) and selected bioinsecticides for controlling the potato tuber moth phthorimaea operculella (Zeller) (Lepidoptera: Gelechiidae) of stored potatoes. J. Plant Prot. Res., 52 (1): 40-46.

Mohamed, A.K. (2002). Evaluation of the efficiency of some chemical compounds on the potato tuber worm. M. Sc. Thesis. Dep. Plant protection. Fac. Agriculture. Al-Azhar University.

Mohamed, I.; M.A.O., Kolaib; M.E.M., Sweelam and M.A., Aboelfadl (2013). Effect of six food types on some biological aspects of the potato tuber moth, Phthorimaea operculella (Zeller) (Lepidoptera,Gelechiidae). Zagazig J. Agric. Res., Vol. 40(5): 927-933.

Sansone, C.G. and R.R., Minzenmayer (2000). Impact of new bollworm insecticides on natural enemies in the southern rolling plains of Texas, in Proceedings of 2000 Beltwide Cotton Conference, ed. by Dugger $\mathrm{P}$ and Richter D. National Cotton Council, Memphis, TN 11041108 .

Sarhan, A.A. (2004). One of the applied biological control programs against the potato tuber moth Phthorimaea operculella (Zeller) in stores. Egyptian J. Biol. Pest Control, 14 (1): 291-298.

Shady, A.M.; A.E., Khalil and M., Shawky, Samaa (2007). Impact of certain mineral fertilizers (NPK) on Meloidogyne incognita on potato in Egypt. African potato Association Conference Proceeding vol. 7. pp.298-304, Alex. Egypt.
Sharshar, A.A.H.; E., El-Hassanein; S., Shaltout, Omayma; M., Yousry, Mona and M., Ahmad (2015). Determination of the Critical Period for Weed Control on Potato (Solanum tuberosum, L.) Crop. Middle East Journal of Agriculture. 4(2): 240-290.

Shoeb, Mona, A. and A.M., Mostafa (2004). Performance and efficacy of some pesticides on the larvae of potato tuber moth. Bull. Ent. Soc. Egypt, Econ. Ser., 30, 183-190.

Temerak, S.A. (1979). Field management of the potato tuberworm, Phthorimaea operculella (Zeller), infesting certain potato varieties through manipulation of different levels of irrigation. Bull. Soc. ent. Egypte, 62 : 155-160.

Toppozada, A.A.S.; S. Abdallah and M.F. El-Defrawi (1966). Chemsterilization of larvae and adults of the Egyptian cotton leafworm, Prodenia littura by apholate, metepa and tepa. J. Econ. Entomol., Vol. 59: 1125-1128.

Tunaz, H. and N., Uygun (2004). Insect growth regulators for insect pest control. Turk. J. Agric. 28: $377-387$

Umadevi, M.; P.K., Sampath, kumar;Debjit Bhowmik and S., Duraivel (2013). Health benefits and cons of Solanum tuberosum. Journal of medicinal plants studies. 1(1):16-25.

Vaneva-Gancheva, T. and Y., Dimitrov (2013). Chemical control of the potato tuber moth Phthorimaea operculella (Zeller) on tobacco. Bulgarian Journal of Agricultural Science, 19(5), 1003-1008.

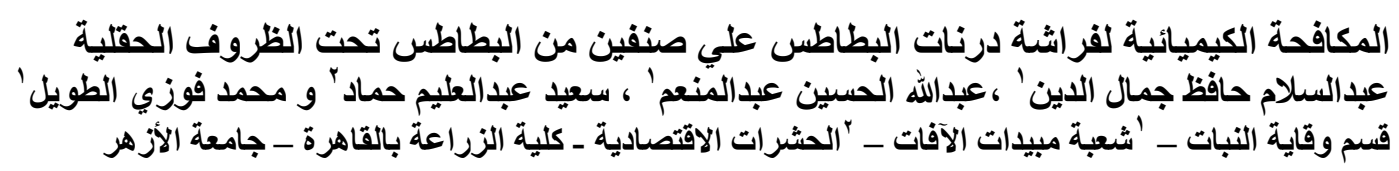

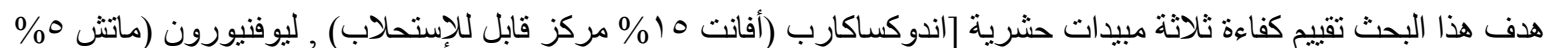

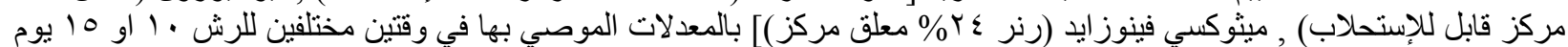

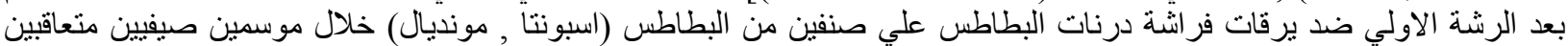

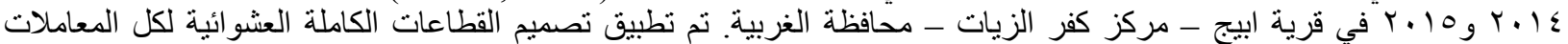

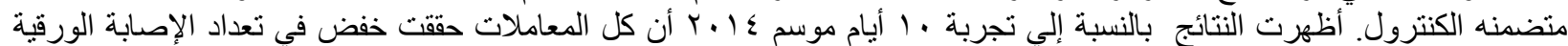

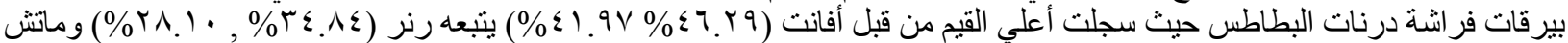

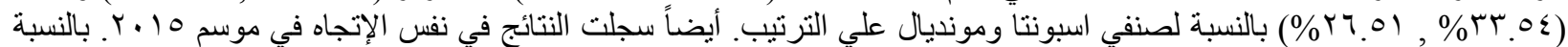

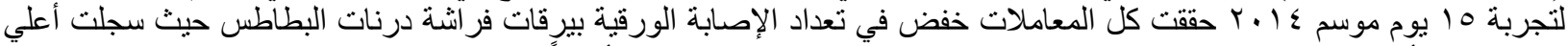

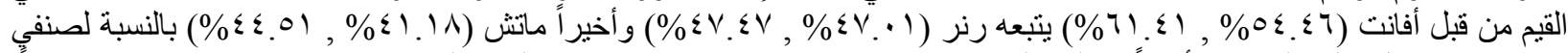

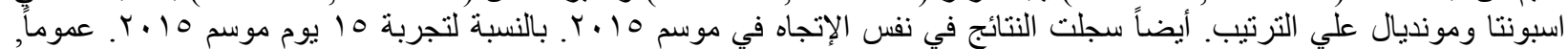

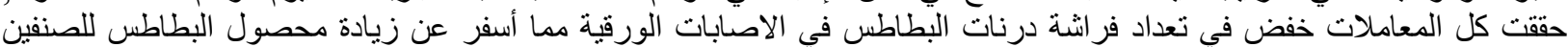

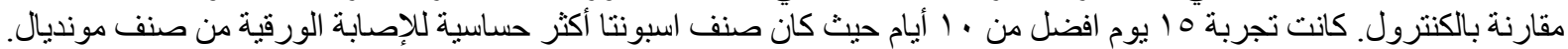

